\title{
Novo perfil produtivo e dinâmica espacial de Curitiba: uma leitura a partir das fases do desenvolvimento regional da economia brasileira e das recentes mu- danças no padrão de produção industrial
}

\author{
Jackson Teixeira BITTENCOURT
}

Dissertação de Mestrado: Curso de Mestrado em Geografia - UFPR

Data da defesa: 26 set. 2003

Banca:

Olga Lúcia C. de Freitas Firkowski (orientadora)

Silvia Maria Pereira de Araújo

Luís Lopes Diniz Filho

\section{RESUMO}

Neste trabalho analisa-se o novo perfil produtivo e a dinâmica espacial da região de Curitiba à luz das fases do desenvolvimento regional da economia brasileira e das transformações ocorridas nos padrões de produção, bem como dos determinantes da localização industrial. O desenvolvimento regional pode ser caracterizado por quatro fases: os arquipélagos regionais ou isolamento relativo, articulação comercial, articulação produtiva e desenvolvimento regional difuso. Nestas quatro fases, procurou-se compreender a inserção do Paraná e principalmente da região de Curitiba na matriz produtiva nacional e no processo de internacionalização da produção, bem como as alterações em sua estrutura produtiva. O novo perfil produtivo está relacionado com os complexos de produção flexível, destacando a indústria automobilística de veículos leves. A localização industrial vem se adequando às novas formas de produção e de arranjo produtivo, dando origem à empresa em rede. Assim, conclui-se que Curitiba passou a assumir uma nova espacialidade, a qual chamouse neste trabalho de cidade-região global de Curitiba, e um novo segmento industrial - material de transportes de veículos leves (as montadoras) -, o qual esta espraiado pela cidade-região global de Curitiba, alterando a funcionalidade do município de Curitiba (núcleo da cidade-região), não mais calcado na produção de bens de capital, mas sim em um prestador de serviços produtivos.

\section{Palavras-chave:}

Perfil produtivo, dinâmica espacial. 